\title{
A BRIEF HISTORY AND ANALYSIS OF INDONESIA'S FOREST FIRE CRISIS'
}

\section{Paul K. Gellert}

\section{Introduction}

Two major events of 1997 and 1998 - the forest fires and smoke covering Southeast Asia and the worst financial crisis since the beginning of President Suharto's New Order-have made it safe to say that Indonesia has lost its invisibility. ${ }^{2}$ On the surface, the fires and the crisis seem like unrelated events which each emerged from a series of causes beyond the regime's control. One could be forgiven for thinking that the fires were simply a natural crisis. Obviously, the regime could do nothing to control the periodic warming of ocean currents known as the El Niño Southern Oscillation (ENSO), which brought extended drought to the country. Similarly, the long-praised "sound fundamentals" of Indonesia's economy seemed unshakable until (and even after) Thailand's currency crisis led to a parallel currency crisis and investor lack of

\footnotetext{
${ }^{1}$ Appreciation is due to the WWF-Indonesia Program for forwarding information, the Indonesia- $\mathrm{L}$ and Indonesia-P lists for providing a steady stream of information, and the host of websites available on the fires, especially that of the IFFM (Integrated Forest Fire Management) project of GTZ (Gesellschaft für Technische Zusammanarbeit) (http://smd.mega.net.id/iffm/). Also, thanks to Deborah Homsher for inviting me to write this piece (and patiently waiting for the result) and to Eveline Ferretti for reading an earlier draft. The viewpoints expressed and the errors are my own responsibility.

${ }^{2}$ Scholars of Southeast Asia and Indonesia in particular have reflected on their lesser status among the cocktail party circuit who still wonder whether Indonesia is somewhere "near Bali." The catchphrase identifying Indonesia as an "invisible" nation is from Donald K. Emmerson, "Invisible Indonesia," Foreign Affairs 66 (Winter 1987/88): 368-387.
} 
confidence in Indonesia's economy-and its political present and future. ${ }^{3}$ That these two events occurred roughly in the same period seemed to be the worst of historical accidents.

However, I argue in this paper that the fire and financial crises are closely related. Both seemingly "natural" crises are generated by the particular political economy of natural resource-based development in Indonesia over the last three decades. The fires are the outcome of three decades of opening Indonesia's forests to exploitation and the export of timber products. This pattern of forest exploitation has culminated most recently in the over-rapid conversion of much of Sumatra and Kalimantan into plantations. The financial crisis is the outcome of the unfettered deregulation of the banking sector in the last ten years and deregulation of private investment generally to finance natural resource development and dubious pet projects of the regime. Both have emerged in response to the structural demands of mobile capital. ${ }^{4}$ Both have also ironically been couched in the nationalistic claims of Indonesia's political and economic leaders who argue that these actions are necessary for "development." The nationalism of the New Order is initially convincing; it seems realistic for a developing country facing a hostile international environment that requires market insertion and economic growth at all costs to facilitate development. At least, the New Order has argued, the natural resources are being (should be) exploited for the benefit of Indonesians. However, the contemporary "nationalism" is surreal and unconvincing if compared to the more broadly based nationalism of the earlier Sukarno era or the era marked by Indonesia's struggle for national independence from the Dutch. The number of actual beneficiaries who profit from today's New Order "nationalism" is small, and almost all these beneficiaries have direct links to Suharto himself.

The fires, then, provide an opportunity to analyze the pattern of development and to point out some of its ecological and social contradictions. The opportunity may be brief. While the existence of Indonesia may have penetrated the global consciousness for good, interest in the forest fires, unfortunately, may evaporate as soon as the smoke clears. Ironically, the proposed solutions to the financial crisis, represented both by the IMF bailout and the policies advocated by those who currently wield political and economic power in Indonesia, do not auger well for a nation that seeks to avoid any recurrence and escalation of the fires, nor do they seem likely to enhance the welfare of and opportunities available to forest dwellers.

I divide my argument into four parts. In the first, I review the history of interaction between natural and anthropogenic causes of the earlier great fires in East Kalimantan (Indonesian Borneo). In the second, I briefly summarize the available data on the 199798 fires. Then, in the third section, I look at the history of timber and forestry development from logging to industrial tree and agricultural tree crop plantations. In the final section, I examine the politics of blame and accountability that continue to thwart the development of alternatives.

\footnotetext{
${ }^{3}$ In addition to the World Bank and the IMF, the Australian economist Hal Hill has been perhaps one of the most enthusiastic in lavishing praise on Indonesia. See, for example, Hal Hill, "Indonesia's Industrial Policy and Performance: 'Orthodoxy' Vindicated," Economic Development and Cultural Change 15,1 (1996): 147-174.

4 See Jeffrey Winters, Power in Motion: Capital Mobility and the Indonesian State (Ithaca, NY: Cornell University Press, 1996).
} 


\section{Lessons Not Learned}

"[I]f human activity continues to intensify, the next major fire event will be much worse." 5

In 1982-83 a series of well-known fires burned 3.2 million hectares of forest in East Kalimantan. These fires were more extensive and also more thoroughly researched than any previous fires in the region. German foresters and their Indonesian colleagues, especially, produced comprehensive studies of the event. ${ }^{6}$ Out of these and other studies came a new appreciation of the naturalness of fire in the tropics, particularly Kalimantan, and more importantly, of the growing impact of humans on the spatial extent and intensity of burning. They also point to the fact that the lessons that could have been gleaned from these previous fires were not learned; the reason for this failure, I would argue, is the political economy of resource extraction in Indonesia.

\section{The Naturalness of Fire and Anthropogenic Factors}

Forest ecologists have begun to recognize the natural importance of fire and the dangers of complete fire suppression. In the US, for example, fire is now understood as critical to healthy regeneration of certain ecosystems, such as prairies in the midwest. Total fire prevention, the sort of policy advocated in the old Smoky the Bear campaigns, carries with it the danger of ultimately producing more intense fires due to excessive build-up of flammable material; the disastrous fires that have visited Yellowstone National Park and southern California residential areas make this lesson clear. In the everwet (or perhumid) tropics, the situation is different since the rapid cycling of organic material means that little organic waste accumulates on the forest floor. Yet in the tropics, too, there is a "natural" fire regime, though it hardly resembles that of temperate zones. ${ }^{7}$

In East Kalimantan, Goldammer and Seibert have found charcoal residue evidence of ancient wildfires that were Carbon-14 dated between circa 17,510 BP and $350 \mathrm{BP}$. These dates reveal that "wildfires occurred not only during the dry Pleistocene, but also after the present wet, rain forest climate stabilized, at about 10,000 to 7,000 BP."8 Goldammer and Seibert argue further that during the last glaciation the lowland Sunda shelf (off present-day Borneo's east coast) and today's remnant lowlands were drier and experienced "frequent droughts and fires," thereby preventing a few

\footnotetext{
${ }^{5}$ Harold Brookfield and Yvonne Byron, South-East Asia's Environmental Future: The search for sustainability (New York: United Nations University Press, 1993), p. 267.

${ }^{6}$ See W. Schindele, W. Thoma, and K. Panzer, Investigation of the Steps Needed to Rehabilitate the Areas of East Kalimantan Seriously Affected by Fire: The Forest Fire 1982/83 in East Kalimantan, Part I: The Fire, the Effects, the Damage and Technical Solutions, FR- Report No. 5 (Feldkirchen: Deutsche Forstservice GmbH, 1989).

7 The everwet tropics are distinguished analytically by biologists from the seasonal or monsoon forests, but both are included in the term "tropical moist forest." In the everwet tropics, every month has rainfall over $100 \mathrm{~mm}$ or there are only short dry spells of a few days or weeks. T. C. Whitmore, An Introduction to Tropical Rain Forests (Oxford: Clarendon Press, 1990).

${ }^{8} \mathrm{~J}$. G. Goldammer and B. Seibert, "The Impact of Droughts and Forest Fires on Tropical Lowland Rain Forest of East Kalimantan," in Fire in the Tropical Biota: Ecosystem Processes and Global Challenges, ed. J. G. Goldammer (New York: Springer-Verlag, 1990), pp. 12-13.
} 
66 Paul K. Gellert

dominant species from creating species-poor communities. ${ }^{9}$ In sum, it becomes clear that although some fires occur naturally in these regions, they tend to be extremely rare, and the conditions that lead to fires return at geologic time intervals that are centuries long.

The huge fire event of 1982-83 was clearly sparked by conditions that existed as a result of both natural weather patterns and human intervention. Beginning in June 1982, East Kalimantan (and Sabah) did experience its worst drought since 1878, and the natural stress was severe in the lowlands nearer to the east coast. ${ }^{10}$ In some areas, up to 70 percent of the commercial-size trees (over $60 \mathrm{~cm} \mathrm{dbh}$ : diameter at breast height, measured in centimeters) died from drought. ${ }^{11}$ Subsequent studies of the fires, though, indicated that humans had contributed to the disaster in more ways than simply by lighting the match in a year of severe ENSO drought. Though government officials and loggers tended to lay the blame on shifting cultivators-small farmers-for setting the fires in this period, in fact the industry itself was the main culprit, for it had disturbed large areas of forest by logging and consequently made those areas more vulnerable to fire.

The role of logging was confirmed by the data (see Table 1). In the region affected by the fires, 69 percent of the area was forested, and most of this forest had been disturbed to some degree. The area of disturbed forest that burned was six times as large as the area of shifting cultivation land that burned.12 More significantly, the percent of forested area affected by fire was highest in the moderately and heavily disturbed areas. The logging industry was thus clearly implicated in exacerbating the fires. The peripheral damage created by selective logging contributed to the problem by leaving large amounts of combustible material on the forest floor, creating canopy openings that led to growth of additional understory vegetation, and by creating "highways" where logs had been extracted through which the fires could penetrate the forest. ${ }^{13}$

${ }^{9}$ J. G. Goldammer and B. Seibert, "Natural Rain Forest Fires in Eastern Borneo During the Pleistocene and Holocene," Die Naturwissenschaften 76 (1989): 519. This view is controversial because it implies that biodiversity is the result of disturbance, not diversification under stable conditions. But, in a period of increasing recognition by geographers, ecologists and others of the lack of truly pristine, untouched environments, the view is less surprising. In fact, the high level of diversity in shifting cultivators' managed gardens has been highlighted recently. See, for example, C. Padoch and N. L. Peluso, eds. Borneo in Transition: People, Forests, Conservation, and Development (New York: Oxford University Press, 1996).

${ }^{10}$ The upland regions in the middle of the island of Kalimantan/Borneo generally experience higher rainfall, upwards of $4,000 \mathrm{~mm}$ per year in typical years, and have been less affected by drought and fire both in the 1980 s and 1990 s.

11 Cynthia Mackie, "The Lessons Behind East Kalimantan's Forest Fires," Borneo Research Bulletin, 16,2 (1984), 63-74.

12 Without going back to the original German study, one cannot be sure how the areas of shifting cultivation were defined, for instance whether calculation included cultivated areas only or also included fallow areas.

${ }^{13}$ C. Mackie, "The Lessons," p. 65. It is important to note that these are effects of logging under the rules of the Indonesian Selective Logging system, although they are surely exacerbated in cases where companies illegally returned to logging blocks sooner than permitted, that is before thirty-five years had elapsed. 
Table 1

Burned and Unburned Areas of Vegetation and Land-Use Types in East Kalimantan 1982-83 Forest Fires

\begin{tabular}{|c|c|c|c|c|c|c|}
\hline & \multicolumn{6}{|c|}{ Area } \\
\hline \multirow[t]{2}{*}{ Vegetation/Land-use Types } & \multicolumn{2}{|c|}{ Total } & \multicolumn{2}{|c|}{ Burned } & \multicolumn{2}{|c|}{ Unburned } \\
\hline & $\begin{array}{l}\text { ('000 } \\
\text { ha) }\end{array}$ & $(\%)^{\mathrm{a}}$ & ('000 ha) & $(\%)^{b}$ & $\begin{array}{l}\left({ }^{\prime} 000\right. \\
\text { ha) }\end{array}$ & $(\%)^{b}$ \\
\hline I. Mixed lowland forests & 3244 & 69 & 2175 & 67 & 1069 & 33 \\
\hline A. Undisturbed forest & 410 & 9 & 46 & 11 & 364 & 89 \\
\hline B. Disturbed forest & 2807 & 60 & 2103 & 75 & 704 & 25 \\
\hline 1. lightly & 1096 & 23 & 636 & 58 & 460 & $\overline{42}$ \\
\hline 2. moderately & 984 & 21 & 827 & 84 & 157 & 16 \\
\hline 3. heavily & $\overline{727}$ & 15 & 640 & $\overline{88}$ & 87 & 12 \\
\hline II. Converted to Plantations & 27 & 1 & 26 & 96 & 1 & 4 \\
\hline III. Limestone/ rock forest & $\overline{43}$ & $\overline{1}$ & 24 & 56 & 19 & $\overline{44}$ \\
\hline IV. Kerangas / heath forest & 40 & 1 & $\overline{18}$ & 45 & $\overline{22}$ & 55 \\
\hline $\begin{array}{l}\text { V. Peat/freshwater swamp } \\
\text { forest }\end{array}$ & $\overline{566}$ & 12 & 405 & $\overline{72}$ & $\overline{161}$ & 28 \\
\hline A. Undisturbed & 181 & 4 & 30 & 17 & 151 & 83 \\
\hline B. Disturbed & 385 & 8 & 375 & 97 & 10 & 3 \\
\hline VI. Other swamp vegetation & 110 & 2 & 90 & 82 & 20 & 18 \\
\hline $\begin{array}{l}\text { VII. Brackish swamp } \\
\text { vegetations }\end{array}$ & 22 & $\overline{0}$ & 5 & 23 & $\overline{17}$ & $\overline{77}$ \\
\hline VIII. Tidal forests & 41 & 1 & $\mathbf{0}$ & $\mathbf{0}$ & 41 & 100 \\
\hline TOTAL FOREST AREAS & 4066 & $\overline{86}$ & 2717 & 67 & 1349 & 33 \\
\hline IX. Shifting cultivation & 387 & 8 & 329 & 85 & 58 & 15 \\
\hline $\begin{array}{l}\text { X. Permanent } \\
\text { cultivation/settlement }\end{array}$ & 213 & $\overline{5}$ & 147 & 69 & 66 & 31 \\
\hline XI. Water bodies & 67 & 1 & 0 & 0 & 67 & 100 \\
\hline TOTAL STUDY AREA & 4733 & 100 & 3193 & 67 & 1540 & 33 \\
\hline
\end{tabular}

Source: Nengah Wirawan, "The Hazard of Fire," in South-east Asia's Environmental Future, ed. Harold Brookfield and Yvonne Byron (New York: UN University Press, 1993), Table 11.1, based on Schindele, Thoma, and Panzer, The Kalimantan Forest fire 1982-3 in East Kalimantan Part I (1989).

Notes: $\quad a=$ percentage of the total study area of $4,733,000$ hectares.

$b=$ percentage (burned or unburned) of the particular vegetation type

In addition to noting which sorts of areas proved more vulnerable to fire, one can also distinguish by type and intensity of fire. The undisturbed forests generally suffered surface fires that damaged the undergrowth, which can recover more quickly than the canopy. However, Wirawan and the German study found that fires in loggedover areas were canopy fires of varying intensity. In "lightly disturbed" forest, fires burned the lower and middle layers of the canopy; in "moderately disturbed" forest, the fire reached some of the upper canopy as well; and in "heavily disturbed" forest, 
"the whole forest structure was destroyed by the fire and the surviving trees occurred primarily as scattered individuals or groups of individuals."14

Finally, in a period when the spatial extent of plantations was still small in Kalimantan, research about the fires did not draw much attention, but there were ominous results in the German study. Only 27,000 hectares of forest in the fire region had been converted, but fire destroyed this area almost completely (96 percent). Comparably complete burning occurred ( 97 percent) in the somewhat larger area of disturbed peat and freshwater swamp forest. At the other end of the spectrum, only 11 percent of the undisturbed lowland forest and 17 percent of the undisturbed swamp forest burned. By the late 1990s, with large-scale plantation development and the more recent million hectare ricefields mega-project underway in Central Kalimantan's swamp forest, these uses had become much more significant. The vulnerability of such developed areas to fire was the most important lesson not learned from the early 1980 s.

\section{The 1997-98 Drought and Fires}

The data is not all in yet, but it is already clear that the 1997 and 1998 fires are the most extensive since the 1982-83 fires, and in the end they may exceed them. While these two conflagrations demand our attention, it should be noted that between 198283 and 1997-98 a number of smaller but significant drought and fire events occurred in Indonesia, particularly in 1989, 1991, and 1994-95. The last, in 1994-95, prompted complaints from Singapore and Malaysia about the smoke and "haze" blowing in from Indonesia. The Minister of Forestry responded to these complaints in early 1995 by banning the practice of clearing land with fire. But it was not until late 1997 that both the effects and the complaints reached their latest crescendo.

Different agencies have offered different estimates of the extent of the damage. Official Indonesian estimates as of early October were that a mere 80,000 hectares had burned, but NGOs have produced much higher figures. The Indonesian environmental organization, WALHI (Wahana Lingkungan Hidup Indonesia) estimated that 1,714,000 hectares of forest had burned from April through September 1997.15 This figure was broken down by area as follows: tree crop plantations accounted for 798,000 ha (ha=hectare) (46 percent) of the total area burned; production forest accounted for 578,000 ha (34 percent); the peat forest project area accounted for 260,000 ha (15 percent); conservation forest areas accounted for 45,000 ha ( 3 percent); transmigration areas accounted for 30,000 ha ( 2 percent); and shifting cultivation areas accounted for 3,000 ha (virtually 0 percent) of the total area burned. WWF (the World Wide Fund for Nature) estimated that only 800,000 to 1 million hectares had burned in the same period, but by year's end WWF had revised its estimate to at least 2 million hectares

\footnotetext{
14 N. Wirawan, "The Hazard of Fire," p. 250. In defining disturbance, "lightly disturbed" seems to refer to areas 75 percent logged, "moderately disturbed" to areas 80 percent logged, and "heavily disturbed" to areas 80 percent logged, where logging occurred within the eight years prior to the fire.

15 "Hasil Investigasi Wahana Lingkungan Hidup Kerugian Rp. 11 Triliun Akibat Kebakaran Hutan," Suara Pembaruan, October 23, 1997. The Rp. 11 trillion ( $\$ 2.2$ billion at a Rp 5000 exchange rate) monetary value was estimated based on $\mathrm{Rp} 380.3$ billion of lost transportation business, Rp. 40 billion of lost fuel sales to Pertamina, Rp. 1.091 trillion of lost trade in thirteen provinces, and Rp. 10.284 trillion of forest losses.
} 
burned. ${ }^{16}$ The economic losses-especially from short-term health damages and tourism and industrial production downturns-were estimated to be $\$ 1.4$ billion.

As happened before, notably in 1982-83, the most recent fires are occurring in an El Niño year, with characteristic drought creating dry conditions by the middle of the year. In fact, El Niño years have occurred more frequently in the 1990s than in the previous four decades (see Figure 1 "Southern Oscillation Index"). ${ }^{17}$ The early months of the most recent ENSO (El Niño Southern Oscillation) were more severe than during the 1982-83 event (see Figure 2 "Southern Oscillation Index, 1997/98 and 1982/83 compared), and by mid-May GTZ's Integrated Forest Fire Management project had sounded warnings that the risk of fire was great. ${ }^{18}$ News of rampant forest fires in Kalimantan, Sumatra, and Irian Jaya began to appear in July as the season for burning-particularly by plantations-began. Later fires were reported in Sulawesi and Java as well.

\section{Figure 1}

\section{SOUTHERN OSCLGATION NDEX}

1947 to 1997

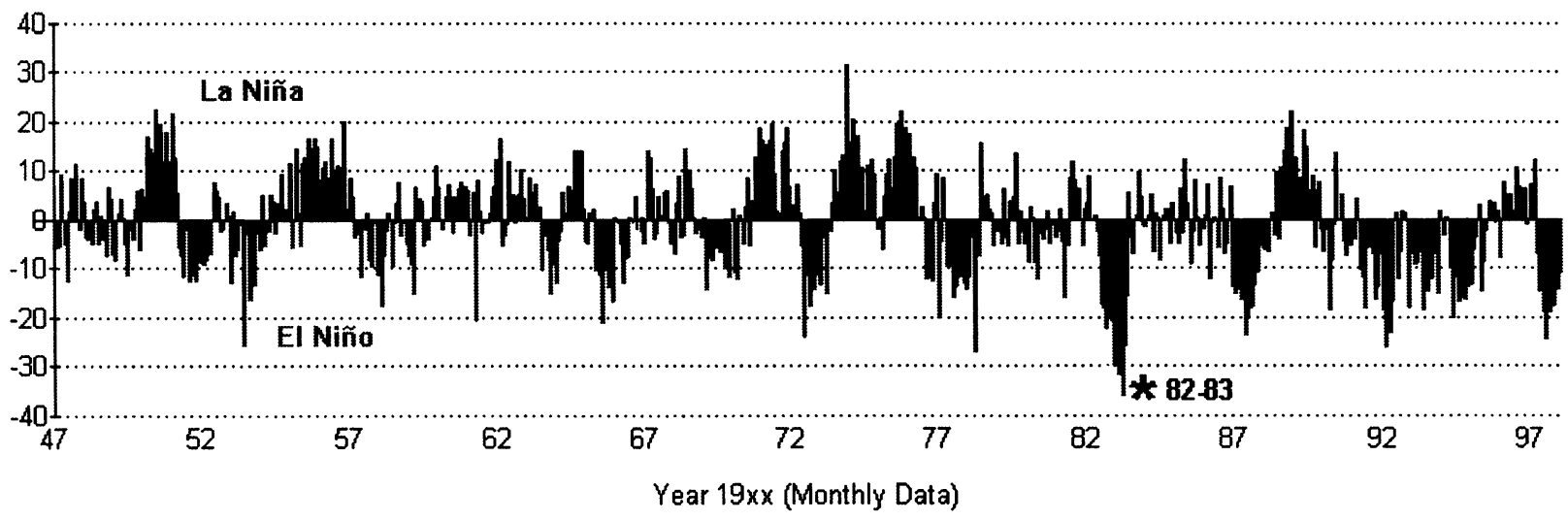

(C) John Daly, at http:www.vision.net.au/ daly/elnino.htm

\footnotetext{
16 Nigel Dudley and Jean-Paul Jeanrenaud, "A Burning Issue: Forest Fires in Indonesia and the Amazon," Interim Report for WWF (http://www.geocities.com/RainForest/2701/burn.html) and Fernando Gonzales, "Update on the Forest Fires in Indonesia," WWF-IP, March 24, 1998.

17 Some have speculated that climate change has contributed to increasing severity and frequency of the ENSO events, although Nichols, "ENSO, Drought, and Flooding Rain in Southeast Asia," in Brookfield and Byron, South-East Asia's Environmental Future (1993) doubts it.

18 See IFFM's web page. The Southern Oscillation Index (SOI) compares sea level pressure in Tahiti and Darwin. Measurements for 1998, when compared with measurements for 1982, showed a greater drop through June but somewhat less extreme readings from July through March. Nonetheless, Indonesia continued to experience its most severe drought in decades.
} 
Figure 2

\section{SOUTHEDN OSCILLATION INDEX (SOI)}

\section{$1997 / 98$ and $1982 / 83$ compared}

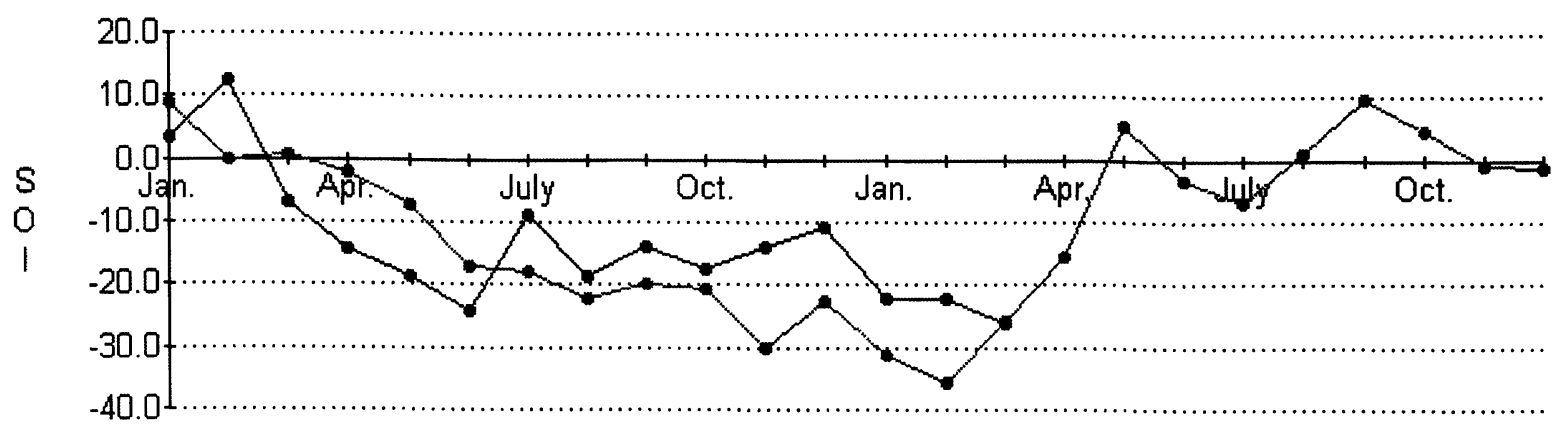

Data: DNR, Queensland, Australia

$-1982 / 83 \rightarrow 1997 / 98$

(C) John Daly, at http:www.vision.net.au/ daly/elnino.htm

\section{International Haze and Attention}

More than the fires, it is the smoke or "haze" that has caught people's attention and created international controversy this time. ${ }^{19}$ The cycles of international attention given the Indonesian fires and related developmental issues have come and gone with the winds that carry the haze. These actual winds tend to move north and west from Indonesia towards the Malay peninsula from April or May through November. As a result, in August, September, and October, the haze overwhelmed Singapore and Malaysia. It was equally if not more thickly concentrated inside Indonesia, but international news reports tended to emphasize the effects in the neighboring countries.

Indonesia's neighbors complained vociferously for a time. ${ }^{20}$ As the Air Pollution Index (API) in Kuching, Sarawak, exceeded the extremely hazardous level of five hundred for a number of days-even hitting 849 (!)-PM Mahathir Mohammad

\footnotetext{
${ }^{19} \mathrm{Haze}$ is defined as a high concentration of particulate matter, and in forest fire haze smaller particulates, less than ten micrograms in size, predominate. These smaller particles are more likely to be carried deep into the lungs and thus are of special concern, especially if they are loaded with carcinogenic compounds. The Air Pollution Index (API) and the similar Pollution Standards Index (PSI) correspond to levels of particulate concentration in the air. See "Haze Guide," Integrated Forest Fire Management Project (Samarinda, Indonesia, 1998) on their web page: http://smd.mega.net.id/iffm/haze.htm.

One of the reasons that the haze may have been worse this time is that peat deposits of up to twenty meters depth have burned in Riau and in the areas of peat forest of Central Kalimantan drained for President Suharto's one million hectare ricefields mega-project.

${ }^{20}$ In November, the Malaysian government, aware that Malaysian and Indonesian elites were bound to each other by a network of shared interests and overlapping ownership of plantations, actually "ordered scientists and environmentalists at state-funded universities to stop commenting about the country's haze problem." See "Malaysia Orders Hush on Haze," Associated Press, November 6, 1997.
} 
donned a face mask and declared a state of emergency in Sarawak. ${ }^{21}$ In Singapore, the Straits Times published a series of color satellite images, including before-and-after shots on the front page, showing that forests were being cleared for plantations. ${ }^{22}$

The immediate effects of the haze on health, as well as basic economic activity, were tremendous. Thousands of people were treated in Malaysia and elsewhere for respiratory and eye complaints; schools and businesses were closed; and air flights were canceled frequently in Indonesia (Sumatra and Kalimantan), Malaysia (Sarawak), and the Philippines (Palawan and Mindanao). As the smoke reached southern Thailand, it had a negative effect on tourism in the whole region.

By the end of 1997, however, attention to the fires was waning. ${ }^{23}$ Sufficient rains had come to Sumatra and western Kalimantan to put out some fires and diminish the haze. Perhaps some Indonesian companies had stopped burning under threat of losing their cutting licenses from the government. For shifting cultivators, the season for burning had passed, as the annual cycle of cultivation is such that burning typically peaks around August and September; by the end of the year, these cultivators were more often busy trying to stop fires from spreading to their fields. As the levels of smoke decreased, more people became convinced that the rainy season had finally arrived, ending the problem for good. The larger history of ENSO events was ignored and long-term weather forecasts inside Indonesia suppressed, allowing this ephemeral glint of hope to survive for a few months. ${ }^{24}$

In early 1998, however, the fires "came back." As in previous El Niño years, the drought persisted into the first few months of the second calendar year. Because rains continued to fall, though sporadically and below normal levels, in western Kalimantan and Sumatra, the location of the most extensive and severe fires moved to East Kalimantan, where it was reported that no rain at all had fallen in the eighty-five days from late January through April $20 .{ }^{25}$ The haze did not become a major problem in Singapore and Malaysia again until late February as the winds started to shift, but Indonesia's neighbors are justifiably worried that last year's fire and haze crisis will repeat itself as we head into the normally drier months (May through October). However, at the April meeting of ASEAN (Association of Southeast Asian Nations) environmental ministers, everyone agreed to do nothing to combat the East Kalimantan fires because they were already out of control. There was inclusive

\footnotetext{
21 "Haze Overwhelms Singapore, Sarawak in State of Emergency," Kompas Online (English edition), September 20, 1997. An API of 100 is considered "unhealthy" and one of 300 or more "hazardous."

22 "Fires Spread Across Indonesia, Blazes in Malaysia," Reuters, October 1, 1997.

23 A number of the web pages that emerged in August and September to cover the fires have not been updated since.

24 During a brief trip to Indonesia around the New Year, I was told by a forestry consultant that TV broadcasters had been instructed by the military not to provide long-term forecasts of further drought, given the political dangers of unrest in the run-up to the March re-election of President Suharto. This consultant also accurately predicted the return of the fires by the end of January.

25 Ed Colijn, "News from Kalimantan," April 20, 1998 (http://www.bart.nl/ edcolijn/). The fires did not disappear from other regions completely; for example, the Straits Times reported more fires on plantations in Riau on February 17. The shifting fields of attention are indicative of the broader problems posed by governmental policymakers and media analysts who rely on technical fixes and focus on the fires as problem rather than symptom.
} 
discussion about establishing a fund to fight fires in the region and an appeal for foreign contributions. ${ }^{26}$

Satellite images are providing daily updates on the "hot spots." 27 On April 16, 1998 , for example, the number of "hot spots" visible on NOAA (National Oceanic and Atmospheric Administration) satellite images of (most of) Borneo was 853. This number had fluctuated over time due to difficulties obtaining accurate and complete images given the cloud (and haze) cover. Readings in the prior weeks had included low and high reports of 23 and 971 hot spots (on March 21 and 8, respectively). The real number of fires probably has not fluctuated as much, but we should assume the numbers may well be greater than satellite images indicate, since those images cover large areas where data is unavailable due to cloud (and smoke) cover. ${ }^{28}$

Regular updates on the spatial extent of the fires are available in the press from the Environmental Impact Management Agency and the Forest Service (Dinas Kehutanan) of East Kalimantan; presumably these are also based on satellite images. From January through April 18, they reported that 393,724 ha of forest had burned and estimated the value of the losses to be Rp 7.3 trillion. ${ }^{29}$ Five days earlier, when the official count was at 231,308 ha, it was broken down by land classification: 32 percent occurred in industrial timber estate (HTI) areas; 31 percent in Kutai National Park, which has had perennial illegal logging intrusions; 24 percent in logging concession (HPH) areas; 3 percent in shifting cultivation fields and forest fallow (semak belukar); and 2 percent in the Mt. Soeharto Tourist Forest. ${ }^{30}$

On the one hand, such updates and figures are remarkable coming from inside the typically opaque and secretive Indonesian government. On the other hand, they give the false impression that, by counting, the government is able to somehow control the fires or even hold people responsible for them. There is good reason to doubt that the Indonesian government will effectively confront, assign responsibility for, and eventually begin to solve the problem of the fires. What is not in doubt, given the 198283 experience and the great percentage of the 1997-98 fires occurring in areas affected by plantation agriculture and extensive (legal and illegal) logging, is that the degree of ecological damage has been severe and forest recovery (if it happens at all) will occur over centuries.

\footnotetext{
26 "Let Fires Burn in Indonesia's E. Kalimantan-ASEAN," Reuters, April 4, 1998.

27 NOAA satellite "hot spots" are areas of $1.1 \mathrm{~km} 2$ with high temperature over 48 degrees celcius detected. There may be a number of fires within such an area.

28 One of the numerous places where satellite images are updated regularly is the GTZ Integrated Forest Fire Management website (http://smd.mega.net.id/iffm/).

29 "Bukit Soeharto Dipapas jadi 30 Ribu ha," Suara Kaltim Online, April 20, 1998. At an exchange rate of Rp. 8,500 , that would be about US $\$ 850,000$. Unlike the case with the WWF study, it is difficult to determine (at least from newspaper reports) exactly what losses are being calculated, i.e. only timber losses or non-timber and other economic losses too.

30 "Sudah 231 Ribu Hektar, Hutan dan lahan Kaltim yang Terbakar," Suara Kaltim Online, April 13, 1998. Because of the drought and fire-related losses of food and habitat, the orangutan population is severely threatened as well. At times one gets the impression that more effort goes into saving these noble animals than stopping the fires or helping the human inhabitants of the forest. See, "OrangutansVictims of East Kalimantan Forest Fires," Kompas Online, April 13, 1998.
} 


\section{Fires and Economic Crisis: The Historical Causal Connection}

How did Indonesia get into the present situation, where both the area threatened by the fires and the intensity of the fires themselves is steadily increasing? One has to look back to the historical development of Indonesia's forest sector and the pattern of economic development of the New Order to discover the causes. In the early period of the New Order, oil revenue provided the basis for development. Since the 1979 and 1982 drops in world oil prices, however, Indonesia has been searching for ways to develop non-oil industries. The effort has borne fruit, but most of these non-oil industries have been natural resource-based industries. In particular, they have been and continue to be based in the forests of Indonesia.

We can identify three stages in the process that has led to increasing exploitation of Indonesia's forests: first, the creation of a large Indonesian plywood industry; second, the push for an Indonesian pulp and paper industry; and most recently, expansion of oil palm plantations. Each of these initiatives, ironically, has been launched with the argument that it will contribute to "sustainable development" and that it will create national, Indonesian development, as opposed to exploitation by foreigners. In reality, however, these stages of forest-based development have progressively undermined the integrity of the tropical forest ecosystems and created concentrated control of the forest trees and land. ${ }^{31}$

\section{Apkindo and Indonesian Plywood Marketing}

Since the late 1980s, plywood has been Indonesia's leading non-oil export. The legal basis for the growth of Indonesia's plywood industry was the 1982 joint ministerial decree from Forestry, Industry and Trade which phased-out and then eliminated by 1985 the export of raw logs. It is worthwhile remembering that one of the initial rationales for this move into downstream processing of raw timber was a criticism of loggers by environmentalists-especially criticism of foreign logging and trading companies from Japan and America-that Indonesia's forests were being decimated at an excessive rate. After the New Order regime opened the forests of the "Outer Islands" to logging in 1967, log exports boomed, reaching an official peak of about 10 million $\mathrm{m} 3$ of wood in 1979. By the end of the 1970s, criticisms were mounting against a logging industry that pursued unsustainable harvesting levels and practices without providing any "national" benefits from those harvests and against logging concessionaires who had never fulfilled their promises to establish downstream processing in-country. ${ }^{32}$

\footnotetext{
31 For similar processes of progressive external control-and resistance to it-in Java's forests, see Nancy L. Peluso, Rich Forests, Poor People (Berkeley: UC Press, 1992).

32 The Indonesian government had been interested in developing wood industries for a long time. A Workshop between foreign and domestic industrialists and government officials was held in 1974 to discuss ways to achieve the targeted 18 percent annual growth in wood industries for Repelita II 1974/75 1979/80. See Proceedings from Workshop on Wood Industries for Export, 17-19 December 1974, Jakarta, organized by the National Export Development Board (Badan Pengembangan Ekspor Nasional) in cooperation with the Indonesian Timber Community (Masyarakat Perkayuan Industry or MPI). MPI later changed to the Indonesian Forestry (Perhutanan) Community and became the umbrella organization over Apkindo and other timber producing associations with cartel-like ambitions.
} 
Despite all the criticism that has been launched against the Indonesian Wood Panel Association, Apkindo, and its leader (until his recent appointment as Minister of Trade and Industry) Mohamad "Bob" Hasan, the achievements of this organization are significant. ${ }^{33}$ Global timber markets tend to be very competitive due to the multiple sources of timber and the potential substitution of both temperate wood and nonwood (e.g. aluminum window frames) for tropical wood. In the face of such competition and the power of Japanese consumers and plywood producers, Indonesia managed to break into the Japanese market and take over a large share of tropical plywood production from Japan, Korea, and Taiwan. It thereby transformed itself from just another source of raw materials into a producer in control of over 70 percent of the tropical wood market. The power to do so came from the size of Indonesia's resource base and, importantly, the internal control over competition amongst producers by Apkindo, which set export prices, quantities and destinations, and beginning in 1990 with the creation of Nippindo in Japan, created exclusive marketing and distribution outlets overseas. ${ }^{34}$

The domestic result of success in marketing plywood overseas has been overcapacity and a correspondingly rapacious appetite for raw materials. Based on estimates of wood recovery rates, the Indonesian wood products industry of which plywood is the dominant product requires over forty million cubic meters of wood per year, but the sustainable rate of timber harvest, according to official Indonesian documents, is twenty-six million cubic meters. ${ }^{35}$ In addition, Apkindo's power has over time led to an increasingly concentrated ownership and control of the forestry sector. The large and powerful firms have been able to avoid sanctions for transgressions against government regulations, and they have acquired additional forest areas as the first twenty-year concessions have expired. In East Kalimantan, the largest eight groups control over two-thirds of the forest concession area.

\section{Pushing Plantations}

At the same time as Indonesian plywood exports were growing in the late 1980s, the Indonesian government began to acknowledge depletion of the forests and express concern about the potential lack of raw materials to feed the industry. After fifteen years of intensive logging in the forests of Kalimantan and Sumatra, the signs of degradation were widespread. Both the 1985 IIED (International Institute for Environment and Development) study and the 1990 FAO (Food and Agriculture Organization) study of the forestry sector of Indonesia found that a great deal of the

\footnotetext{
33 Christopher Barr's essay on Apkindo in this issue is a strong indictment of Hasan's personal control of the plywood trade, but Barr also acknowledges the role of the organization in breaking into international timber markets. For a more detailed discussion of this, see Paul Gellert, "The Political Economy and Ecology of Indonesia's Timber Industry, 1967-1995," PhD dissertation, University of Wisconsin-Madison, 1998.

34 This led South Korean importers to protest openly about unfair trade practices to Indonesia's Minister of Trade, Satrio B. ("Billy") Joedono. See Vincent Lingga, "Plywood Exports Fall in Wake of Apkindo Tug of War with Korea," Jakarta Post, October 27, 1994. Joedono, who spoke about the need for changes in the running of the Apkindo organization in 1994, was later forced out of the cabinet by a reorganization that merged trade and industry, in the wake of the controversy over the national car project. In the 1998 cabinet, Hasan became the new Minister of Industry and Trade.

35 Ministry of Forestry, Indonesia Tropical Forestry Action Plan (Jakarta: Ministry of Forestry, 1992).
} 
forest had been degraded. ${ }^{36}$ Therefore, the government of Indonesia began calling for the development of industrial tree plantations (hutan tanaman industri or HTI) as the key element in the new "sustainable forestry" policy. It exemplified this shift with the appointment of Hasjrul Harahap, who came to the Ministry of Forestry from Agriculture in 1988 due to his expertise and previous experience in tree crop plantations in Sumatra.

The twin rationale for the HTI program-it was meant to (1) increase the yield from "production" forests to fulfill the pressing demand of the timber industry and (2) rehabilitate "unproductive" or "degraded" forest land-had been laid out in 1983.37 The idea of turning "degraded" secondary forest land into productive (plantation) forests appealed to the Department of Forestry, the timber industry, and international financial institutions like the World Bank. For the foresters, this strategy seemed to hold the promise of reforesting large areas of degraded forest, albeit under monoculture plantations. The World Bank and a number of economists approved of the policy, as it promised to make unproductive lands more productive and bring them into the market economy.

For the industrialists, however, the policy was attractive for two simple reasons. First, it gave them access to the forest. While the Indonesian Forestry Community's public relations efforts have emphasized the sustainable logging practices of the selective logging and replanting (TPTI) system in Indonesia, the industry has relied increasingly on wood from clear cuts (Ijin Penebangan Kehutanan or IPK). In East Kalimantan, for example, the targets for IPK cutting increased from $333,000 \mathrm{~m} 3$ in $1990 / 91$ to over one million $\mathrm{m} 3$ in $1994 / 95.38$ The actual (official) volume of IPK cutting in 1993/94 was $836,638 \mathrm{~m} 3$, and since selective felling produced 4,436,731 m3 in the province that year, the harvest from clear cuts equaled a significant proportionnearly one-fifth - of the harvest gained from selective logging. ${ }^{39}$

All of this cutting belies the notion that the plantations were being established on "degraded" or so-called "unproductive" forest lands, lands covered with grass (Imperata cylindrica, especially) or secondary brush. The grasslands are notoriously difficult and expensive to convert to plantations, and the companies are less interested in "degraded" lands, which by definition are areas with less than twenty cubic meters

\footnotetext{
36 IED/GOI (Government of Indonesia), A Review of Policies Affecting the Sustainable Development of Forest Lands in Indonesia (Jakarta: International Institute for Environment and Development and Government of Indonesia, 1985); FAO/GOI, Situation and Outlook of the Forestry Sector in Indonesia, 5 vols. (Jakarta: Food and Agriculture Organization and Directorate General of Forest Utilization in the Ministry of Forestry, Government of Indonesia, 1990).

37 SK Menhut No. 20/Kpts-II/1983 translates as, "HTI development is one of the activities for reforestation and regeneration for increasing the potential of production forest in order to guarantee the supply of raw materials for industry and is an effort to rehabilitate production forests that are not productive." Cited in WALHI, "Hutan Tanaman Industri: Blunder Kedua Kebijakan Kehutanan di Indonesia," Jakarta, February 1995 (?). Legally, the 1983 decree was followed by SK Menhut No. $320 / 1986$ tentang Pembangunan HTI and PP No.7/ 1990 tentang Pengusahaan HTI.

38 Data provided to author by Kanwil Kehutanan Kalimantan Timur.

39 Dinas Kehutanan Kalimantan Timur, Dinas Dalam Angka 1993/94 (Samarinda: East Kalimantan Forest Service, 1994).
} 
per hectare of commercial timber (over $30 \mathrm{~cm} \mathrm{dbh).}{ }^{40}$ Environmentalists have rightly been critical of this natural subsidy provided to the industry, as well as the low level of replanting efforts by loggers once they have gotten the wood.

The second reason for industrial enthusiasm has been the financial subsidization of Indonesia's campaign to become the world's largest pulp and paper producer. Money from the Reforestation Fund (Dana Reboisasi or DR) has been used to fund plantations. Officially, 14 percent of the investment in private plantations and 35 percent of the investment in state-owned plantations can come from the fund. An additional 32.5 percent is available from the DR in interest-free loans. In practice, it has been argued, the owners of plantations can use the capital for their own purposes if they make only minimal efforts in those subsidized plantations. In at least two cases (involving Suharto's half-brother Probosutedjo and Bob Hasan), there have been accusations of the DR money going to fund the multimillion or billion dollar pulp mills. ${ }^{41}$

One of the unanswered questions at this point with regard to HTI plantations and burning is to what extent companies have actually planted. Government figures perennially show planting to be far behind target. Also, the NGO critiques of IPK have implied that many areas are never developed into even fast-growing eucalyptus, acacia or albizia plantations. If that's true, there would not be much real incentive to clear the land (by fire or any means) after the bigger trees are harvested, unless it is to satisfy government monitors that an initial planting effort has been made. The prospects for oil palm and other agricultural crop plantations (perkebunan), on the other hand, are obviously good enough to encourage clearing and real planting efforts.

\section{Oil Palm Plantations}

The development of palm oil plantations is the new factor in the forest fires of 1997-1998. In fact, like the fires themselves, palm oil is not new in Indonesia, however the pace and form of development of palm oil plantations is unprecedented. Spurred by government encouragement based on high market prices and a "nationalist" desire to beat Malaysia in this lucrative market, Indonesia's crude palm oil (CPO) exports were over a billion dollars in 1997. Such expansion has relied on rapid land clearing by burning (mimicking shifting cultivators on a large-scale) and thus contributed directly to the extent of this year's forest fires. ${ }^{42}$

Consider, again, the province of East Kalimantan. In 1980, none of the utilized agricultural land was allocated to estates; this contrasted with South and West Kalimantan, where a quarter to half the land was in estates. ${ }^{43}$ In fact, the farm land

\footnotetext{
40 WALHI, Hutan Tanaman Industri (Jakarta: WALHI, 1994), p. 18. See also, Larry Lohmann, "Freedom to Plant: Indonesia and Thailand in a Globalizing Pulp and Paper Industry," in M. Parnwell and R. Bryant, ed. Environmental Change in South-East Asia (New York: Routledge, 1996).

41 See G. van Klinken, "Reforestation Fund," Inside Indonesia Digest 46 (December 8, 1997).

42 See Table 2 for the areas under palm oil. The fact that fires have not been nearly as extensive on the Malaysian side of Borneo speaks both to the slower pace of plantation development there and stricter enforcement of bans on burning.

${ }^{43}$ M. Pangestu, "East Kalimantan: Beyond the Timber and Oil Boom," in H. Hill, ed., Unity and Diversity: Regional Economic Development in Indonesia since 1970 (New York: Oxford University Press, 1991), p. 170. The remaining categories and percentages for East Kalimantan are human settlement ( 9.6 percent), wet rice sawah (11.1 percent), dry field (67.9 percent), and mixed agriculture (11.4 percent). A higher percent
} 
dedicated to growing leading crops-rubber, coconuts, pepper, and cocoa-in 1985 together amounted to a mere 61,900 hectares, and less than one-fifth of that was in large estates. In 1991, the Indonesian economist Mari Pangestu could still write, "Estate crops play a very minor role in East Kalimantan's economy." 44 The reasons for this lack of estate crop development included the poor infrastructure for transporting goods out, the low population density and thus lack of available labor, and the relatively poor quality of the soils.

But the growth of palm oil plantations in the 1990s has been astonishing. In January 1995, the Regional Forestry Office (Kanwil) of East Kalimantan had applications for 1.4 million ha of plantations, 990,000 ha of which were for palm oil. ${ }^{45}$ If these applications are implemented, estates will encompass an area ten times larger than 1985. On a national level, the actual increase was over four times (see Table 2, following). More recent data shows the importance of Riau in the conversion of over seven million ha to plantations in the late 1990s (see Table 3, following).

In an interesting twist, the fires of the 1980s may have paved the way for this development. A 1991 analysis noted that, although Kalimantan's forest cover was still considerably above the national average in all four provinces of Kalimantan, both Central and East Kalimantan had been "designated a major target for future estate crop and industrial wood plantations (HTI)" and in East Kalimantan this was to be "largely in areas affected by the 1982-83 fire[s]."46 Ironically, this means that the areas partially damaged by fire before may be ignited and set burning again to prepare the way for plantations in the 1990s in the name of "sustainable development."

\section{The World Bank Steps In}

As Indonesia moved to expand tree crops more generally it had full World Bank support. In 1986, the Bank reported a shift in its role from supporting subsistenceoriented transmigration of the population to encouraging tree crop agriculture. One key reason for the shift was the criticism the Bank had received for its role in the transmigration program, which by 1986 had moved 613,700 families from "overpopulated" Java, Bali, and Madura to "underpopulated" Kalimantan, Irian Jaya, and elsewhere. ${ }^{47}$ Transmigration had resulted in deforestation through conversion for settlements and agricultural fields and failed in efforts to alleviate poverty because the generally poor quality soils in places like Kalimantan could not support rice subsistence on small plots of land.

(36.6 percent) of cultivable land is utilized in East Kalimantan then in other Kalimantan provinces, but in East Kalimantan cultivable land makes up a mere 5.3 percent of total land area.

44 Ibid.

45 The data may be woefully incomplete as it only includes Kutai, Pasir, and Bulungan regencies. Data provided to author by Kanwil Kehutanan Kalimantan Timur, 1995.

46 J. Dick, "Forest Land Use, Forest Use Zonation, and Deforestation in Indonesia: A Summary and Interpretation of Existing Information," prepared for the State Ministry for Population and Environment (KLH: Kantor Lingkungan Hidup) and the Environmental Impact Management Agency (BAPEDAL: Badan Pengendalian Dampak Lingkungan), June 1991. Quotations from page 36.

47 The figure, which refers to "sponsored" transmigrants and does not include the partially assisted or unassisted ones, is from World Bank, Indonesia: Sustainable Development of Forests, Land, and Water (Washington DC: The World Bank, 1990), p. 33. 
78 Paul K. Gellert

Table 2

Palm Oil Production in Indonesia, 1975-1994, tons and percent of total

\begin{tabular}{|c|c|c|c|c|c|c|c|}
\hline Year & \multicolumn{2}{|c|}{ Public Estates } & \multicolumn{2}{|c|}{ Private Estates } & \multicolumn{2}{|c|}{ Smallholder } & Total \\
\hline & Tons & $\%$ & Tons & $\%$ & Tons & $\%$ & \\
\hline 1975 & 271171 & 68.3 & 126082 & 31.7 & - & & 397253 \\
\hline 1976 & 286096 & 66.4 & 144910 & 33.6 & - & & 431006 \\
\hline 1977 & 336891 & $\overline{73.6}$ & 120716 & 26.4 & - & & 457607 \\
\hline 1978 & 336224 & 67.1 & 165060 & 32.9 & - & & 501284 \\
\hline 1979 & 438756 & 68.4 & 201724 & $\overline{31.5}$ & 760 & $\overline{0.1}$ & 641240 \\
\hline 1980 & 498858 & 69.2 & 221544 & 30.7 & 770 & 0.1 & 721172 \\
\hline 1981 & 533399 & 66.7 & 265616 & $\overline{33.2}$ & 1045 & 0.1 & 800060 \\
\hline 1982 & 598653 & 67.5 & 285212 & 32.2 & 2955 & 0.3 & 886820 \\
\hline 1983 & 710431 & 72.3 & 269102 & 27.4 & $\overline{3454}$ & 0.4 & 982987 \\
\hline$\overline{1984}$ & 814015 & 71 & 329144 & 28.7 & $\overline{4031}$ & 0.4 & 1147190 \\
\hline 1985 & 861173 & 69.3 & 339241 & 27.3 & 43016 & 3.5 & 1243430 \\
\hline 1986 & 912306 & 67.5 & 384919 & 28.5 & 53504 & 4 & 1350729 \\
\hline 1987 & 988480 & 65.6 & 352413 & 23.4 & 165162 & 11 & 1506055 \\
\hline 1988 & 1102692 & 64.4 & 454495 & 26.5 & 156148 & 9.1 & 1713335 \\
\hline 1989 & 1184226 & 60.3 & 597039 & $\overline{30.4}$ & 183689 & 9.4 & 1964954 \\
\hline 1990 & 1247156 & 51.7 & 788506 & 32.7 & 376950 & 15.6 & 2412612 \\
\hline 1991 & 1360363 & 51.2 & 883918 & 33.3 & 413319 & 15.6 & 2657600 \\
\hline 1992 & 1489745 & 45.6 & 1076900 & 33 & 699605 & 21.4 & 3266250 \\
\hline 1993 & 1469156 & 42.9 & 1370272 & 40 & 582021 & 17 & 3421449 \\
\hline 1994 & 1571501 & 39.2 & 1597227 & 39.9 & 839334 & 20.9 & 4008062 \\
\hline 1995 & 1613848 & 36 & 1864379 & 41.6 & 1001443 & $\overline{22.4}$ & 4479670 \\
\hline 1996 & 1751484 & 35.3 & 2111045 & 42.6 & 1097230 & $\overline{22.1}$ & 4959759 \\
\hline 1997 & 1830960 & 34.2 & 2278846 & 42.5 & 1246735 & 23.3 & 5356541 \\
\hline
\end{tabular}

Source: Indonesian Directorate General of Estates, as presented in D. F. Larson, "Indonesia's Palm Oil Subsector," Policy Research Working Paper 1654 (Washington, DC : The World Bank) for years through 1993; "Menguak Perjalanan CPO," Prospek, February 23, 1998, pp. 16-17, for remaining years. 
Table 3

Change of Status from Production Forest to Conversion Forest for Estate Plantations, through September 1997

\begin{tabular}{|l|r|r|r|r|r|r|}
\hline \multicolumn{1}{|c|}{ Province } & \multicolumn{2}{c|}{ Application $^{\mathrm{a}}$} & \multicolumn{2}{c|}{ Agreement $^{\mathrm{a}}$} & \multicolumn{2}{c|}{$\begin{array}{c}\text { Official Change of } \\
\text { Land Status }\end{array}$} \\
\hline & \multicolumn{1}{|c|}{ No. } & \multicolumn{1}{c|}{ Area (ha) } & \multicolumn{1}{c|}{ No. } & \multicolumn{1}{c|}{ Area (ha) } & \multicolumn{1}{c|}{ No. } & \multicolumn{1}{c|}{ Area (ha) } \\
\hline A. On island of Sumatra: & & & & & & \\
\hline 1. N. Sumatra & 6 & 49300 & 26 & 160313 & 15 & 74070 \\
\hline 2. W. Sumatra & 6 & 110315 & 12 & 51176 & 22 & 121140 \\
\hline 3. Riau & 18 & 176500 & 51 & 593431 & 102 & 1205668 \\
\hline 4. Jambi & 9 & 70290 & 11 & 47181 & 36 & 309393 \\
\hline 5. S. Sumatra & 14 & 289800 & 16 & 94173 & 8 & 42503 \\
\hline 6. Bengkulu & 4 & 28405 & 6 & 25000 & 10 & 42888 \\
\hline 7. Lampung & 2 & 16300 & 4 & 61275 & 5 & 28051 \\
\hline $\begin{array}{l}\text { B. On island of } \\
\text { Kalimantan (Indonesian } \\
\text { Borneo) }\end{array}$ & & & & & & \\
\hline 1. W. Kal & & & & & & \\
\hline 2. C. Kal. & 22 & 372700 & 18 & 127674 & 8 & 89400 \\
\hline 3. S. Kal. & 34 & 516250 & 27 & 1835619 & 32 & 349556 \\
\hline 4. E. Kal. & 2 & 10550 & 6 & 64130 & 18 & 189678 \\
\hline TOTAL & 33 & 634200 & 32 & 444112 & 39 & 269081 \\
\hline
\end{tabular}

Source: "Luas Hutan Yang Dikonversi Untuk Perkebunan 7 Juta Hectare," Suara Pembaruan, October 10, 1997 (http:/ / www.suarapembaruan.com/News/1997 /10/101097/Ekonomi/eko14/eko14.html) from Directorate General of Inventory (Intag), Department of Forestry, 1997.

Notes: ${ }^{\mathrm{a}}=$ Application to and approval by the Department of Forestry, presumably. The source of the official change (SK Pelepasan) is not clear, either the Department of Forestry or Agrarian Affairs (Agraria). $\mathrm{b}=$ Source document had 25 , and I merely assume they meant 25,000 .

The Bank, admitting some of the critique, argued that tree crops could solve several problems at the same time because the tree crops would be ecologically more sustainable, provide foreign exchange to Indonesia, and alleviate poverty for millions of smallholder families. Whereas it had allocated $\$ 560$ million for the transmigration program over the previous decade, it planned to allocate $\$ 680$ million of fresh funds for the establishment of "nucleus estate and smallholder" (NES) estates. ${ }^{48}$ This level of investment clearly played a role in the growth of plantations witnessed in Indonesia.

The NES estate concept called for the "nucleus" of a government-owned estate to be established within a larger "plasma" area of smallholders, who would grow the same crop and sell their produce to the government estate. ${ }^{49}$ In effect, the smallholders

48 Transmigration Sector Review (Washington DC, The World Bank, 1986).

49 Around the same time, the HTI-Trans program was born, which was intended both to assist the timber industry in establishing more fast-growing tree plantations and to provide additional income through employment to transmigrants during the first few years. The HTI-Trans program may have been Bob Hasan's brainchild; it was tried out first at his East Kalimantan Kiani Lestari concession. 
would be living under contract relations with the larger estate. As Michael Dove writes (of rubber),

The project design is based on the assumption that the principal obstacle to the development of smallholdings is their small size and scattered location . . . and, by implication, absence of government control. It is further based on the premise, that the basic problem with smallholdings is the extent to which they are unlike estates. The government solution then is to create smallholdings that are more like estates rather than smallholdings in their capital intensity and economies of scale; and to centralize management under the government as opposed to local management by individuals ... 50

The persistent bias towards large, estate plantations is evident in a recent World Bank working paper on the oil palm sector, although this more recent document is characterized by a 1990s emphasis on private as opposed to state-owned plantations. ${ }^{51}$ It is striking that the World Bank paper omits counting cost of land clearing, which is most cheaply done by fire, in its calculation that figures Indonesian production costs to be "among the lowest in the world." 52 The World Bank paper also fails to take into account fire-related losses.

In sum, land issues are paramount in explaining the fires and the pattern of development in Kalimantan (as elsewhere in Indonesia). Reuters has reported on plantations using arson "to force people off land wanted mainly for oil palms." 53 From the investors' - and the World Bank's-point of view, however, the chief issue has to do with frustrating complications that arise because the smallholders' ownership of private property and clear title to plots of land are difficult to negotiate. Allow me to quote at length from the Bank working paper:

Once a plantation company has identified a potentially suitable site, the company begins a two-pronged approval process. The company first files an application with the Director General of Estates for a location permit. The location permit also requires [application to and] the approval of the local governor.... The estate company conducts a location study which it provides to both the local and central government. Once both applications are approved, the central and local forestry agencies conduct a review of the project's impact. Once this review process is complete, the complicated process of identifying settlers and providing compensation to those settlers is begun. Since the land is infrequently titled, these negotiations can be complicated and intractable.

50 Michael Dove, "So Far from Power, So Near to the Forest: A Structural Analysis of Gain and Blame in Tropical Forest Development," in C. Padoch and N. L. Peluso, eds. Borneo in Transition: People, Forests, Conservation, and Development (New York: Oxford University Press, 1996), p. 47.

51 Donald F. Larson, Indonesia's Palm Oil Subsector, Policy Research Working Paper 1654 (Washington DC: The World Bank, 1996). In the study, smallholder production is included in total palm oil production, but the paper does not specify whether this is tied into the NES program. Clearly there are "transaction costs" in obtaining accurate production cost data on smallholders, but such costs should not pose problems for as large a data-collecting enterprise as the World Bank. All production cost data is for estates.

52 Larson, Indonesia's Palm Oil Subsector, p. 3.

53 "Arson Blamed for Some Indonesian Bush Fires," Reuters, March 5, 1998. 
Following the negotiations, the land is typically leased for thirty years with an option to renew, rather than purchased outright.

The lack of clear title certainly builds a barrier to investment in tree crops. However the implication for smallholders is much broader. Lack of title inhibits transfers of ownership in general, and smallholders who may wish to migrate to better opportunities may have to abandon valued properties. 54

There are several problems inherent in this approach and the assumptions that underlie it, many of which stem from the Bank's tendency to place large investors ahead of smallholders. Notice that the "complicated process" of dealing with individual settlers is only begun after the firm has selected a suitable site for growing palm oil and obtained the approval of the regional and central governments. Notice also that once the firm has selected a site and the process of developing the NES plantation has begun, the working paper published by the Bank recommends that compensation be given to "identified settlers"; in this way, the paper fails to take into account the pre-existing, though not formally recognized, land rights of indigenous groups and the possibility that such groups might not wish to have their land incorporated into a plantation. Also, the logic of the Bank's approach rests on the assumption that granting clear title to property would encourage large numbers of smallholders to migrate to Kalimantan, but this assumption is unfounded. Except in accessible areas near the river cities, there is little evidence that in-migration pressure is significant in East Kalimantan. What is more, since the state retains eminent domain over the land and only leases it to the companies, the rights of smallholders over their own land become even more tenuous. It is not surprising, then, that NES plantations have failed to attract waves of smallholders to the interior, and that instead the tidal movement created by this development seems to flow outward, as the plantation sector grows larger and consequently infringes on the forest product and land rights of indigenous groups.

The financial, economic, and political crisis facing Indonesia may exacerbate the pressures on the forest from plantations. With devaluation of the rupiah (from Rp. 2500 to Rp. 8500) and largely local inputs (i.e. forest and labor), palm oil exports have become more lucrative than ever. Perhaps that is why, in the second and third IMF attempts to bail out the Government of Indonesia (January and April 1998), a condition was inserted that required the nation to open palm oil development to foreign investors. In addition, the $1998 \mathrm{IMF}$ agreement requires that CPO exports are to be allowed again; exports of palm oil were halted in January by government officials concerned to protect domestic supplies of cooking oil, since they feared a shortage might spark social unrest before and around the March re-election of Suharto.

At the time of this writing, it is uncertain whether the Indonesian government will actually lift the export ban and substantially reopen the industry to foreign investment. Bob Hasan is making "nationalist" complaints about the IMF interfering in the development of Indonesia. He repeats his complaints with an air of confidence and sincerity, despite the fact that the small coterie of Suharto's friends and clients who are

54 Larson, Indonesia's Palm Oil Subsector, p. 19. He goes on to suggest that the Bank can assist in land titlement because it has experience in this area. 
82 Paul K. Gellert

now gaining access to the forests for palm oil plantations happen to be the same people who profited from the plywood and timber plantations. ${ }^{55}$

\section{The Political Economy of Blame: Evidence, Diversion, and Power}

"Why should we burn the forests? We need the raw materials. It doesn't make sense." - M. Bob Hasan ${ }^{56}$

"If you do land-clearing in pioneer areas, where no roads are established, the only practical way to get rid of the debris is to burn it." - A. F. S. Budiman, Executive Director of the Rubber Association of Indonesia ${ }^{57}$

"Kalimantan at this time is part of the Wild West, part of a nation without government, like parts of America in the 19th Century." Juwono Sudarsono, Minister of Environment ${ }^{58}$

"The use of fire to aid in clearing land was something English settlers borrowed from their Indian predecessors, but they applied it for different purposes and on a much more extensive scale. Instead of burning the forest to remove undergrowth, they burned it to remove the forest itself." - W. Cronon 59

Who is to blame for the fires? Or perhaps we should be more specific and ask what is the real allocation of blame among smallholders, plantations, and arsonists seeking to grab land? It will probably be years before the detailed technical studies of the 199798 fires are finished. But we need not wait. These studies will not solve the very political problem of allocating blame. If this year's fires have proved anything, it is that knowledge is not the same as power. The satellite evidence that shows fires burning in plantation areas is undeniable, but the question of who actually caused them can (and will) still be debated ad nauseum.

It is in this context that Hasan's rhetoric, a sample of which is quoted above, is more a diversion from taking blame than a real engagement of the political economy of fire in Indonesia's forests. To be sure, the logging companies would prefer not to have the big trees burn before they have a chance to cut them (although the currently depressed timber markets in Japan and the rest of Asia make that preference less clear). But the distinction between logging companies (HPH) on the one hand and timber

55 See G. J. Aditjondro, "Palm Oil Nepotism Adds Fuel to Disaster," Australian Financial Review, October 13, 1997. Also, during my field work in 1995, I met a logging camp manager who was busy studying palm oil because he had been re-assigned to direct the company's new plantation.

56 "Indonesia Timber Barons Deny Blame for Fires," Reuters, September 30, 1997.

57 Margot Cohen with Murray Hiebert, "Where There's Smoke..." Far Eastern Economic Review, October 2, 1997. Budiman went on to explain that if a local official tries to enforce the law against burning, "You just bribe him." After the article was published, Budiman may have suffered for his bluntness, as he complained to Cohen that he had been misquoted (M. Cohen, personal communication, January 1998).

58 Nelson Graves, "Thickening Smog sets off SE Asia Alarm Bells," Reuters, April 14, 1998.

${ }^{59}$ W. Cronon, Changes in the Land: Indians, Colonists, and the Ecology of New England (New York: Hill and Wang, 1983), p. 118. 
estates (HTI) and palm oil plantations on the other is a thin legal line. ${ }^{60}$ In fact, neither Hasan individually nor the logging industry as a whole can separate itself from the land clearing for plantations, since these plantations are often owned in common by a number of cronies and, as we have seen, they supply the plywood industry with raw material. Even when sub-contractors are hired to do the actual forest clearing and land preparation, the industrial owner can hardly claim ignorance or lack of responsibility for the method of clearing. ${ }^{61}$ Fire is simply the cheapest way to clear land.

In contrast to government officials who blamed "slash and burn" shifting cultivators for causing 1982-83 fires, today's officials, notably the former Ministers of Environment and of Forestry, Sarwono Kusumaatmadja and Djamaluddin Suryohadikusumo, have been willing to blame the large industrial actors. ${ }^{62}$ Sarwono was particularly critical towards the end of his term. He called efforts to blame either El Niño or shifting cultivators for the fires "nonsense," and he blamed "irresponsible plantation operators" (orang-orang kebun memang kurang ajar) outright. ${ }^{63}$ On September 15 and 17, 1997, Djamaluddin publicly announced that 176 companies were responsible for the fires burning in Sumatra and Kalimantan and suspended their IPK cutting licenses. Of these, 133 were estate (agricultural tree crop) plantations, twentyeight were industrial tree plantations, and fifteen were transmigration sites. ${ }^{64}$ The Minister gave the companies until the end of the month to prove their innocence. ${ }^{65}$

However, the implementation of the Minister's sanctions has been disappointing. Most of the companies had failed even to respond by the deadline. Perhaps they did not really believe that the Minister was serious. Or, perhaps they knew that the threat would not be implemented. Some of the recalcitrant companies included those of powerful timber tycoons Liem Soie Liong, Prajogo Pangestu (PT Surya Hutani Jaya) and Bob Hasan (PT Kiani Lestari, PT Tanjung Redep Hutani, and PT ITCI Hutani Manunggal). When they finally filled out their reports (BAP: Berita Acara

60 During my research, I had expected to be able to examine both the HPH and HTI operations, at several companies. When I reached the field I discovered that they had split into two companies, for example PT. ITCI and PT. ITCI Hutani Manunggal, and that I therefore would need separate letters of introduction to conduct research at the HTI sites.

61 See "Warga Mengaku Diupah untuk Membakar Hutan," Suara Kaltim Online, March 16, 1998. Thirteen residents of Muara Kedang, Kutai, acknowledged being promised Rp. 11 million to burn an area at night.

62 Hasan, on the other hand, has continued to blame the shifting cultivators as well as "communist" nongovernmental organizations. Unfortunately, many articles in the press, either out of ignorance or the relative ease of access to small farmers over big businessmen, also blame the poor smallholders. Even the venerable New York Times devoted a quarter-page photograph to one such farmer who the caption identified as a man who was busy lighting fires.

63 "Sarwono Kusumaatmadja: Orang Kebun Itu Kurang Ajar," Indonesia Daily News Online, March 14, 1998.

64 "Siapa Membakar Hutan," DER, September 27, 1997, pp. 28-29.

65 The legal status of burning is not exactly clear. Following the 1994-95 fires, Djamaluddin banned burning, and this ban was reiterated by the Minister of Forestry and by the President in September 1997. However, companies also were said to be practicing "controlled burning" (a la restoration ecology in the West) based on 1995 technical guidelines (SK Dirjen Perkebunan No. 38/KB110/SK.BUN/05) from the Director General of Plantations, then in the Ministry of Agriculture, and a 1997 decree with technical guidelines from within the Ministry of Forestry (SK Menhut No. 889/Menhut-VI/1997 and SK Dirjen PHIA No. 47/Kpts/DJ-VI/1997) which was only revoked on October 10, 1997 (SK Dirjen PHPA No. 152/Kpts/DJ-VI/1997). See Green News Indonesia No. 02/Indo/1998. 
Pemeriksaan), they blamed carelessly dropped cigarettes and "other" companies for spreading fire to their areas. What's more, by December most of the 176 licenses had been reinstated, exposing again the Ministry's lack of autonomy and authority. By April 1998 only about five were undergoing prosecution. ${ }^{66}$ It is increasingly difficult to piece together the names of companies and the progress of prosecutions from the Indonesian media. On March 7, East Kalimantan police were said to be investigating twenty-seven companies for illegal burning, and on March 17, one company, PT London Sumatra was convicted of large-scale burning near the Jempang Lakes. ${ }^{67}$

The successful prosecution of a few firms for illegal burning may, ironically, bolster the government and industry's claims of increasing oversight while providing little real change. The maximum reported penalties are some jail time (unlikely, especially for owners) and Rp. 200 million fines (about US\$ 23,000 at present). ${ }^{68}$ Particularly when the firms punished are foreign, such as PT London Sumatera, there is an uncanny fit with the nationalist diversion being played out by the Suharto regime. If Indonesia's timber tycoons can hide behind rhetoric that demands an end to foreign exploitation while at the same time they are allowed to disregard existing Indonesian regulations, we must expect that control of production and trade in the growing palm oil sector will become increasingly concentrated in the hands of these same tycoons and their associates.

Fines for illegal burning also fit into proposed technical solutions to the fires. ICRAF (International Centre for Research in Agroforestry), in an October report, suggested that the problem was "too much smoke in the wrong place at the wrong time."69 ICRAF recommended that, rather than continue to impose "unenforcable bans," the government should analyze and fix the when, where, and perhaps the how of burning. Technical improvements to "fire technology" do have their merit, as those suffering from burning eyes, ruined travel plans, and even serious damage to the lungs can attest. But questions about why there is burning and how much land clearing by burning should be allowed are left unaddressed by ICRAF's recommended policy, and there's the danger.

Changes brought about by the new cabinet appointed in March do not bode well for reform. The insertion of "bun" (perkebunan or agricultural tree crop plantations) into "hut" (kehutanan or forestry) in the new Department of Forestry and Plantations appears to complete a process of ascension by the foresters in Indonesia's political administration. Moving from its subordinate beginnings as a Directorate General under the Minister of Agriculture, Forestry became an independent ministry in 1983. Now, rather than forfeiting jurisdiction over the large areas of forest being converted into tree crops or transformed into transmigration settlements and granting jurisdiction over those lands to the Ministers of Agriculture and Transmigration, the Minister of Forestry has gained permanent control over the allocation of those lands.

66 Angie Ramos, "Interview: Indonesia Not Prosecuting Fire Starters," Reuters, April 15, 1998.

67 Suara Kaltim Online and IFFM, cited in "Update on Fires/Drought in Indonesia, Down to Earth (February/March 1998).

68 MPI, "Briefing Paper: Indonesia's Forest Fires," (Jakarta, October 2, 1997). The errors and misdirection of this briefing paper are too numerous to delineate.

69 Thomas P. Tomich, “Managing Fires to Reduce Smoke,” ICRAF, October 10, 1997. 
To date, however, what the Ministry of Forestry has gained in jurisdiction it has lost in autonomy. As leader of Apkindo and trusted friend of Suharto, Hasan had been referred to as the "real" Minister because of his decision-making power. Now, with his official government capacity elevated to Minister of Industry and Trade, Hasan has seen his powers expanded from control over marketing of forest products to control over all industries.

The IMF solution to the financial crisis, i.e. further opening to foreign capital, is likely to exacerbate this ecological crisis, as well as social conflicts in Indonesia's forests, where they remain less visible than the protests and calls for change in the cities and university campuses. Although the $\mathrm{IMF}^{\prime} \mathrm{s}$ effort to eradicate monopolies and cartels, if successful, may provide the necessary condition for open discussion of the political economy of forestry (and other) policy in Indonesia, it is not sufficient to change the thrust of the developmental model. And its push to allow foreign investment-specifically in palm oil-would surely result in further clearing of the forest. At the same time, it provides fodder for the anti-IMF rhetoric of Suharto and Hasan.

Finally, one can expect continued expansion of plantations in Indonesia and the possibility, if technical solutions do not succeed, of forest fires capturing international attention in future El Niño years. The case of colonial New England is surprisingly instructive. Like the colonial settlers, late-twentieth-century plantation owners in Indonesia's Outer Islands have been using the traditional tool-fire-for land clearing on a much greater scale than indigenous populations before them. The more extensive use of fire led to similar concerns about spreading fire damage in New England, and it also led to technical solutions. As Cronon notes, when the danger of spreading fires was realized in colonial New England, burning was restricted by government regulation to the wettest months of the spring. But the process of clearing and dispossessing the indigenous settlers continued apace, as it has in Kalimantan and Sumatra in the twentieth century. In these islands we do not find, as the new Minister of Environment's statement might indicate, a mythical, and "lawless" Wild West. Rather, we discover a land exploited by a government whose policies insure the accumulation of power, profit, and property by its friends-and, if the IMF has its way, by foreign investors as well-thus threatening the rights of the powerless who live in the forest and the future of the forest itself. 